\title{
PTVG-HP Plasmid DNA Vaccine
}

National Cancer Institute

\section{Source}

National Cancer Institute. pT VG-HP Plasmid DNA Vaccine. NCI Thesaurus. Code C82407.

A cancer vaccine containing plasmid DNA encoding human prostatic acid phosphatase (PAP) (pTVG-HP) with potential immunostimulatory and antineoplastic activities. Upon administration, pTVG-HP plasmid DNA vaccine may stimulate the host immune system to generate a cytotoxic T lymphocyte $(\mathrm{CTL})$ response against PAP-expressing prostate cancer cells. PAP or prostatic specific acid phosphatase (PSAP) is a tumor associated antigen (TAA) that may be overexpressed in prostate cancer. 